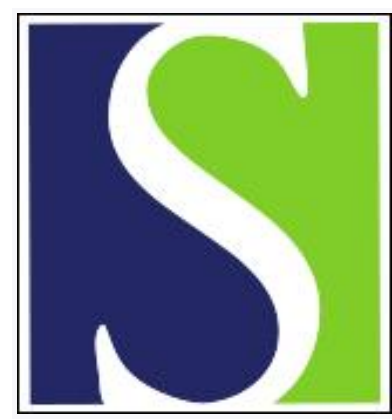

Scand J Work Environ Health 2006;32(4):257-269

https://doi.org/10.5271/sjweh.1009

Issue date: 31 Aug 2006

Systematic review of the qualitative literature on return to work after injury

by MacEachen E, Clarke J, Franche R-L, Irvin E; Workplace-based Return to Work Literature Review Group

Affiliation: Institute for Work \& Health, 481 University Avenue, Suite 800, Toronto, Ontario, M5G 2E9, Canada. emaceachen@iwh.on.ca

The following articles refer to this text: 2010;36(6):515-516;

2011;37(2):99-108; 2011;37(5):359-362; 2012;38(2):93-104;

2015;41(2):204-215; 2015;41(3):219-221; 2020;46(4):364-372;

2022;48(3):173-189

Key terms: injury; meta-ethnographic approach; occupational health; qualitative literature; return to work; review; social relations; synthesis; systematic review; work organization

This article in PubMed: www.ncbi.nlm.nih.gov/pubmed/16932823 


\title{
Systematic review of the qualitative literature on return to work after injury
}

\author{
by Ellen MacEachen, PhD, ${ }^{1,2}$ Judy Clarke, MSc, ${ }^{1}$ Renée-Louise Franche, PhD, ${ }^{1,2}$ Emma Irvin, BA, ${ }^{1}$ the \\ Workplace-based Return to Work Literature Review Group ${ }^{3}$
}

\begin{abstract}
MacEachen E, Clarke J, Franche R-L, Irvin E, the Workplace-based Return to Work Literature Review Group. Systematic review of the qualitative literature on return to work after injury. Scand $\mathrm{J}$ Work Environ Health 2006;32(4):257-269.

Objectives This paper reports on a systematic review of the international qualitative research literature on return to work. This review was undertaken in order to better understand the dimensions, processes, and practices of return to work. Because return to work often includes early return before full recovery while a person is undergoing rehabilitation treatment, physical recovery is embedded in complicated ways with workplace processes and practices and social organization. These process-oriented dimensions of return to work are well described in the qualitative literature.

Methods This systematic review of the literature covered peer-reviewed papers that focused on musculoskeletal and pain-related injuries and were published in English or French between 1990 and 2003. Findings from papers meeting relevance and quality criteria were synthesized using the meta-ethnographic approach.

Results This review found that return to work extends beyond concerns about managing physical function to the complexities related to beliefs, roles, and perceptions of many players. Good will and trust are overarching conditions that are central to successful return-to-work arrangements. In addition, there are often social and communication barriers to return to work, and intermediary players have the potential to play a key role in facilitating this process.

Conclusions This paper identifies key mechanisms of workplace practice, process, and environment that can affect the success of return to work. The findings illustrate the contribution that qualitative literature can make to important aspects of implementation in relation to return to work.
\end{abstract}

Key terms meta-ethnographic approach; occupational health; social relations; synthesis; work organization.

"Return to work" is a practice that was introduced by many workers' compensation boards in North America and Europe throughout the 1990s. Return to work is seen as good practice because it promotes better recovery, leads to less time off work for the worker and lower compensation premium costs for the employer, and it contributes to better management of compensation costs for workers' compensation assurors (1-3).

Return-to-work practices differ in important ways from earlier approaches of vocational rehabilitation. A key characteristic of return to work is early return to the workplace before full physical recovery. This approach means that workers are back in their workplace in some capacity, often modified, while they may still be undergoing treatment such as physiotherapy, and taking medication such as painkillers. With return to work, disability and rehabilitation have become domains of the workplace (4). Health care management has become embedded in complicated ways with workplace mandates such as productivity, and with the complexities of workplace social organization.

This systematic review was undertaken to produce a better understanding of the dimensions, processes, and practices of workplace-based return to work. Although return to work is policy in many jurisdictions and it differs from earlier vocational rehabilitation practices, there has been little systematic assessment of how return to work works. For instance, we know little about the social organization and experience of players involved in return to work, including the processes, priorities, problems, and successes in return to work.

This paper reports on the results of a systematic review of the international literature on qualitative research concerning return to work. We examined studies

1 Institute for Work \& Health, Toronto, Ontario, Canada.

2 University of Toronto, Toronto, Ontario, Canada.

3 Kimberley Cullen, John Frank, Sandra Sinclair, Rhoda Reardon, Anusha Raj, Donald Cole, Victoria Pennick.

Reprint requests to: Dr E MacEachen, Institute for Work \& Health, 481 University Avenue, Suite 800, Toronto, Ontario, M5G 2E9, Canada. [E-mail: emaceachen@iwh.on.ca] 
to determine what they could say about how return to work is organized and practiced and, on the basis of this knowledge, what could lead to best practices for return to work. We defined workplace-based return-to-work studies as those that focus on early return to work (ie, before full recovery) and that take into consideration the workplace environment or the range of key players in the process of workplace-based return to work, such as compensation adjudicators and physicians. This review was part of a larger, mixed-method review in which qualitative and quantitative reviews were conducted concurrently; the relationship between the two components was examined and has been reported elsewhere $(5,6)$, as are the results of the quantitative synthesis $(7)$. 4

The following questions guided the review of the qualitative research:

- What are the social and organizational dimensions of workplace-based return to work?

- What are the challenges for workers, employers, and health care providers in the return-to-work process?

- How can key players in return to work contribute to optimal return-to-work practices?

Systematic reviews of qualitative research studies are a growing phenomenon in the health literature (812). This form of synthesis may be emerging because, as models of evidence-based decision-making develop, policy-makers and other decision-makers realize they need evidence that is broad based in order to make decisions that are both appropriate and implementable. While quantitative studies can measure the effectiveness of return-to-work programs, well-conducted qualitative studies can shed light on dimensions of this practice, as well as on the needs and behavior of workplace parties and other actors in the process. The strength of the qualitative studies reviewed in this report is that they identify the presence and nature of key player interests in return to work, examine day-to-day workplace realities of return-to-work programs, and describe physical, social, and organizational contexts in which return to work occurs. Overall, this synthesis offers a realist perspective of return to work because it takes an explanatory focus and seeks to unpack the mechanism of how complex programs work in particular contexts and settings (13).

\section{Methods}

\section{Search process}

The qualitative articles were retrieved from an initial search for qualitative and quantitative studies involving processes and practices related to workplace-based return to work and interventions aimed at improving return-to-work outcomes for workers with musculoskeletal or other pain-related conditions. The final selection of qualitative articles was made using the following inclusion and exclusion criteria: (i) the study explored the experiences of any of the various players immediately involved in workplace-based return to work, such as employers, co-workers, health care professionals, compensation management professionals, and injured workers; (ii) the study used recognizable qualitative methods ${ }^{5}$; and (iii) the study focused on work-related musculoskeletal and pain-related injuries ${ }^{6}$.

Peer-reviewed papers published in English or French between 1990 and 2003 were included in the search. The sources of these papers were the electronic databases MEDLINE, EMBASE, CINAHL, PsycInfo, Sociological Abstracts, ASSIA (Applied Social Sciences Index and Abstracts), and ABI (American Business Index); other sources included peer-reviewed reports from wellestablished research centers such as the Workers Compensation Research Institute in the United States, the IRSST (Institut de Recherche Robert-Sauvé en Santé et en Securité du Travail), and the Institute for Work \& Health in Canada.

\section{Quality assessment and data extraction}

A modified version ${ }^{7}$ of a qualitative assessment framework developed by researchers based at the National Centre for Social Research (14) in the United Kingdom was used to assess the methodological quality of the papers reviewed (see the appendix for the questions used in the quality assessment). This qualitative research assessment tool was preferred over others because it was engaged with concepts central to qualitative research. In keeping with the iterative and creative nature of qualitative research, this tool was a guideline for the systematic consideration of papers rather than a checklist for procedure. The tool was sensitive to theory, interpretation, and the focus of qualitative research on "what" and "how" questions rather than on hypothesis

This systematic review was conducted by the Institute for Work \& Health in 2004 partly in response to a request from the Workplace Safety and Insurance Board of Ontario. found that it was actually a narrative description of a quantitative survey. Nonpain-related conditions that were excluded were, for example, mental health and permanent disability.

The modification to this framework eliminated a question that pertained specifically to evaluation research and provided additional space for reviewers to record comments and impressions of each aspect of the study under review. 
Table 1. Quality assessment guidelines.

\begin{tabular}{ll}
\hline Rating & Requirements \\
\hline Low & $\begin{array}{l}\text { Data too invariable, due to inadequate analysis or sampling strategy; data do not "ring true" and it appears that the authors had super- } \\
\text { imposed their own set of ideas }\end{array}$ \\
Medium & $\begin{array}{l}\text { Analysis descriptive in nature and somewhat "thin" in describing context and detail, leading to appearance of superficiality } \\
\text { Digh }\end{array}$ \\
$\begin{array}{l}\text { Descriptive but including a more adequate level of analysis, with consideration of context, presentation of a more nuanced picture of study } \\
\text { participants and the complex environment in which they function }\end{array}$ \\
$\begin{array}{l}\text { Required a theoretical focus, with consideration of the internal processes involved in creating the situation that was being described (for } \\
\text { example, links to macro structures), and with an explanatory value that could be transferred to other research arenas }\end{array}$
\end{tabular}

Table 2. Data extraction components.

\begin{tabular}{|c|c|}
\hline Research question & What is the research question? Is the research question answered? Describe \\
\hline $\begin{array}{l}\text { Theoretical orientation } \\
\text { Study method }\end{array}$ & $\begin{array}{l}\text { Describe stated (or implicit) theoretical orientation. Describe if or how theoretical orientation is applied in the analysis } \\
\text { Identify if method includes either/and: interviews (include what type), focus groups, case study, document review, mixed } \\
\text { design, other (specify) }\end{array}$ \\
\hline $\begin{array}{l}\text { Sample and } \\
\text { study context }\end{array}$ & $\begin{array}{l}\text { Describe sampling strategy, number and type of participants, how participants were recruited, geographic locale and time } \\
\text { frame of study, workplace types included }\end{array}$ \\
\hline Analysis & Describe stated (or implicit) analytic process \\
\hline Reflexivity & Describe stated (or assessed) reflections on how methods or theory or sampling approach impacted outcome \\
\hline Study findings & $\begin{array}{l}\text { Provide detailed description of study themes and issues; describe how and why study is relevant to workplace-based return to } \\
\text { work }\end{array}$ \\
\hline
\end{tabular}

testing (15-19). The framework involved 17 questions based on four principles, that research should (i) contribute to advancing wider knowledge and understanding, (ii) provide a defensible research strategy that can answer the questions posed, (iii) demonstrate rigor through systematic and transparent data collection, analysis and interpretation, and (iv) demonstrate credibility with well-founded and plausible arguments about the significance of the data generated.

Each paper was reviewed independently by two experienced qualitative researchers and assessed to be low, medium, high, or very high in quality. (See table 1 for the validity assessment guidelines.) In cases of discrepancy, the reviewers discussed the paper until consensus was achieved. If a consensus could not be reached, a third reviewer was consulted. In five cases in which the reviewers were either authors of, or associated with authors of, papers to be assessed or a French language reviewer was required, the papers were given to external reviewers for assessment.

Data extraction proceeded for the papers assessed as being of medium, high, or very high in quality. The extraction included descriptions of the research question, theoretical orientation, study method, sampling and study context, analysis, reflexivity ${ }^{8}$, and findings. (See table 2 for the data extraction components.) It was conducted by two researchers who organized and worked on the quality assessment. Each independently completed data extraction, after which meetings were held to discuss extraction completeness and relevance.

\section{Synthesis of studies}

The meta-ethnographic approach (20) was used to synthesize the data of the papers included in the review. This approach has been used in other systematic reviews of qualitative health literature $(21,22)$ and is useful because its inductive approach transcends differences in qualitative methodologies and epistemological paradigms. The meta-ethnographic approach involves the following three levels of analysis: first-order concepts, second order interpretations, and third-order syntheses (21). First-order concepts are those identified in the original studies. Second-order interpretations are cross-cutting "key concepts" that encompass more than one of the studies being synthesized. Third-order analyses involve a synthesis of key concepts toward a line of argument. The synthesis is arrived at through a process of reciprocal translation and constant comparison of concepts across studies; its purpose is to arrive at findings on a given conceptual theme for which the results are greater than the sum of the parts (22). The translation of studies into one another encourages the consideration of ideas, concepts, and metaphors across studies and, in doing so, provides explanations not articulated in the literature.

In this synthesis, data extraction provided first-order concepts in the original studies that were relevant to return to work-such as "promotion of early return". Second-order interpretations were developed through the building of eight key concepts, each of which

8 "Reflexivity" in this instance refers to how the authors explain the relationship between the context and events of the data-gathering processes of the study and the study findings. 
encompassed at least 4 of the 13 studies reviewed. Key concepts were arrived at analytically; for instance, the key concept of "trust and goodwill" became relevant when some studies noted consequences of the absence of goodwill—such as employer suspicions about effort and motivation in return to work-and others contributed to a positive picture of goodwill—such as helpful or trusting relationships (see table 3 for the first-order and key concepts). The final analysis included a search for directly comparable findings, oppositional findings, and findings that contributed to a line of argument (21). The final analysis is not a summary or aggregation of findings, but is, instead, a re-interpretation of "key concept" findings according to how they relate to each other on the main theme of workplace-based return to work and the questions guiding the review. Here, for example, our analysis identifies dimensions and challenges of return to work and, on the basis of these findings,

Table 3. First-order and key concepts of the reviewed studies. (RTW = return to work)

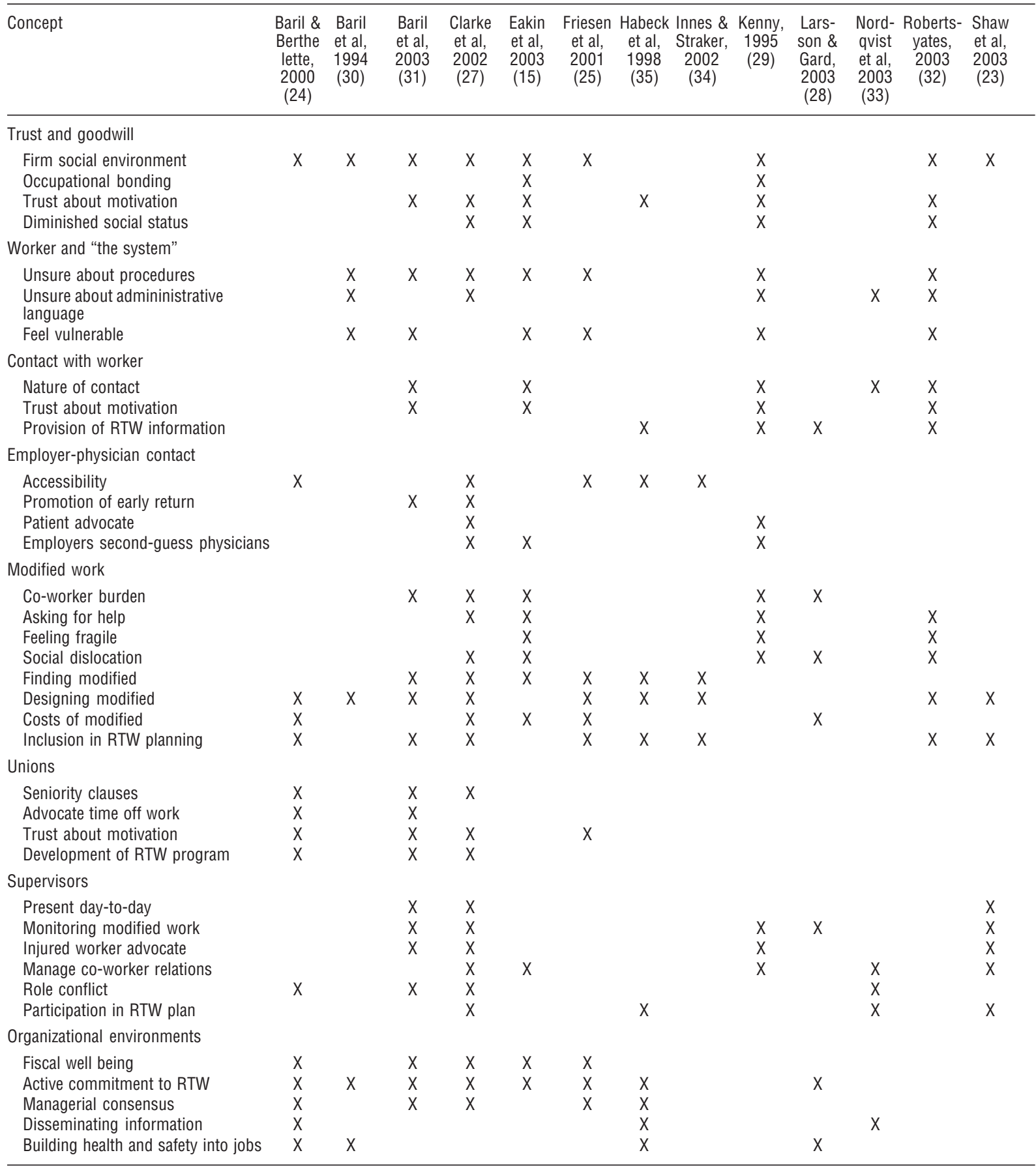


develops an argument for key intermediary players who may contribute to optimal return-to-work conditions.

In practice, this synthesis involved a review of all of the included papers, data extraction findings, and notes from review meetings that detailed comparisons across papers. The synthesis was conducted by the same researchers who organized and worked on the quality assessment and data extraction and who were familiar with the field of return to work. In addition, the qualitative systematic review process and findings were reviewed by the larger steering committee of the mixedmethod review project. (The study methods and foci are summarized in table 4.)

\section{Results}

\section{Results of the search}

From the initial search of eight sources, 4124 studies were identified for possible inclusion in the qualitative or quantitative reviews. Selection of the qualitative studies from among this first search involved a keyword search for the terms "interviews", "focus groups", "observations", "qualitative", or "qualitative methods". This process yielded 229 studies for which the full-text articles were screened to see if they met the inclusion criteria. Fifteen qualitative studies were selected and proceeded to undergo quality assessment (figure 1).

Thirteen studies were judged to be of sufficient quality to proceed to data extraction. (The studies proceeding to data extraction are listed in table 4.) At this stage of the review, most of the studies passed the quality assessment because we included studies of medium quality (more on issues of quality follow) and because we had already screened out many studies with a quasiqualitative design that did not stand up to methodological scrutiny. Altogether 7 of the 13 studies were judged to be of medium quality, 5 were of high quality, and 1 was of very high quality.

\section{Key concepts and meta-ethnographic synthesis}

Eight key concepts were identified across the 13 studies. This section describes the key concepts and their relevance to the meta-ethnographic analysis.

Role of goodwill among parties. A key concept and synthesis finding of this systematic review of qualitative studies of workplace-based return to work is that, whether parties actually collaborate in the return-to-work process is dependent on goodwill and local culture, even when the procedures met the standards of good practice, such as a proactive approach to injury (23-25). The concept of goodwill was present in most of the studies reviewed, either in a discussion of its presence or mention of its absence. Goodwill is an intangible, but influential factor that affects workplace ideas about the attribution of injury, the magnitude of resources allocated to return to work and prevention $(24,26)$, the ability to negotiate the process successfully, and the level of creativity applied to planning and managing modified work $(27,28)$. The conditions for goodwill exist largely in the social environment of the firm. For instance, goodwill is more likely to exist when a worker has "occupational bonding" or job attachment with employers and co-workers (29) or "capital" in the "moral economy" 9 of a firm (26). In these situations, the worker is sufficiently respected that workplace parties are motivated to make the necessary effort to create conditions for a successful return to work.

Several studies examined the absence of goodwill and discussed the consequences of this absence. An absence of goodwill exists among workers if they feel that managers or health care providers are not acting in their best interests and that other issues, such as cost savings and production statistics $(26,29,30)$ and timely case closure, are an implicit priority. These conditions may undermine worker motivation to cooperate with returnto-work efforts $(31,32)$. In turn, employers may lack motivation to commit fully to return-to-work policies when they suspect that a worker has taken advantage of an injury to reduce effort at work. This atmosphere of suspicion can lead to "social hardening" or disillusionment about the feasibility of return-to-work objectives on the part of the employer, who may resolve to be less accommodating to injured workers (26).

The studies showed that the social environment of a firm can affect worker recovery. Several studies found that, during the return-to-work process, injured workers experience diminished social status, feelings that they do not fit in, and a need to justify the genuineness of injury to their employers, co-workers, and friends (32). Workers also feel under scrutiny about the validity of their injuries and their entitlement to compensation and time off work (26). These social conditions may contribute to psychological trauma (32) and physical reinjury, as workers attempt to demonstrate the veracity of their injury by taking actions such as ignoring physical restrictions or returning to work against medical advice (26).

Relations between the worker and "the system". Several studies noted aspects of workers' compensation and

"Moral capital" is a financial metaphor to illustrate informal social give-and-take commitments, expectations, and relationships in a workplace. For further explanation, see the report of Eakin et al (26). 
Table 4. Summary of study methods and foci. ( $Q A=$ quality assessment, $R T W=$ return to work)

\begin{tabular}{|c|c|c|c|c|c|c|}
\hline Study & Location & Method & Participants & Recruitment & $Q A$ & Focus of study \\
\hline $\begin{array}{l}1 \text { Baril \& } \\
\text { Berthe- } \\
\text { lette, } 2000 \\
(24)\end{array}$ & $\begin{array}{l}\text { Quebec, } \\
\text { Canada }\end{array}$ & $\begin{array}{l}\text { Qualitative component } \\
\text { of mixed-methods stu- } \\
\text { dy; interviews, review } \\
\text { of collective agreements }\end{array}$ & $\begin{array}{l}16 \text { employers, } 4 \text { workers and } \\
\text { compensation system representa- } \\
\text { tives (number not reported) in } \\
16 \text { companies }\end{array}$ & $\begin{array}{l}\text { Companies selected from } \\
\text { compensation files }\end{array}$ & Medium & $\begin{array}{l}\text { Organizational } \\
\text { determinants of } \\
\text { early RTW } \\
\text { interventions }\end{array}$ \\
\hline $\begin{array}{l}2 \text { Baril et al, } \\
2003(31)\end{array}$ & $\begin{array}{l}\text { Three } \\
\text { Canadian } \\
\text { provinces }\end{array}$ & $\begin{array}{l}\text { Interviews, focus groups, } \\
\text { document review }\end{array}$ & $\begin{array}{l}\text { Workplace parties ( } 65 \text { employers, } \\
25 \text { workers) plus a variety of sta- } \\
\text { keholders outside of workplace } \\
\text { (health care, vocational profes- } \\
\text { sionals, insurance providers, } \\
\text { union representatives) }\end{array}$ & $\begin{array}{l}\text { Sampled for variation in } \\
\text { workplaces (size, sector) }\end{array}$ & High & $\begin{array}{l}\text { Stakeholder per- } \\
\text { ceptions about } \\
\text { effective RTW }\end{array}$ \\
\hline $\begin{array}{l}3 \text { Baril et } \\
\text { al, } 1994 \\
(30)\end{array}$ & $\begin{array}{l}\text { Quebec, } \\
\text { Canada }\end{array}$ & $\begin{array}{l}\text { Mixed methods study } \\
\text { (qualitative and quantita- } \\
\text { tive); former involved } \\
\text { semi-structured interviews }\end{array}$ & $\begin{array}{l}\text { Workers, employers, union repre- } \\
\text { sentatives, health professionals, } \\
\text { rehabilitation counselors (total } \\
68 \text { ) }\end{array}$ & $\begin{array}{l}\text { Worker sample chosen to } \\
\text { represent different RTW situa- } \\
\text { tions, in } 3 \text { regions of Quebec }\end{array}$ & Medium & $\begin{array}{l}\text { Stakeholder per- } \\
\text { ceptions about } \\
\text { rehabilitation of } \\
\text { injured workers }\end{array}$ \\
\hline $\begin{array}{l}4 \text { Clarke et } \\
\text { al, } 2002 \\
(27)\end{array}$ & $\begin{array}{l}\text { Ontario, } \\
\text { Canada }\end{array}$ & $\begin{array}{l}\text { Semi-structured inter- } \\
\text { views }\end{array}$ & $\begin{array}{l}17 \text { workplace parties (occupa- } \\
\text { tional health nurses, physicians, } \\
\text { health \& safety coordinators, } \\
\text { union representatives, administra- } \\
\text { tor); supplementary data from } \\
\text { workers, health care providers, } \\
\text { compensation professionals }\end{array}$ & $\begin{array}{l}\text { Sample chosen for variation } \\
\text { in experience and company } \\
\text { size, based on information } \\
\text { from municipal publications, } \\
\text { word-of-mouth, snowball } \\
\text { sample, physicians in one } \\
\text { city, local labor council }\end{array}$ & High & $\begin{array}{l}\text { Stakeholder per- } \\
\text { ceptions about } \\
\text { RTW process }\end{array}$ \\
\hline $\begin{array}{l}5 \text { Eakin et al, } \\
2003(15)\end{array}$ & $\begin{array}{l}\text { Ontario, } \\
\text { Canada }\end{array}$ & $\begin{array}{l}\text { Semi-structured inter- } \\
\text { views }\end{array}$ & $\begin{array}{l}17 \text { employers, } 22 \text { workers from } \\
\text { small business settings; } \\
4 \text { compensation professionals }\end{array}$ & $\begin{array}{l}\text { Referred compensation } \\
\text { board, health \& safety orga- } \\
\text { nizations, community orga- } \\
\text { nizations, labor organiza- } \\
\text { tions, medical and legal aid } \\
\text { clinics and personal referrals }\end{array}$ & $\begin{array}{l}\text { Very } \\
\text { high }\end{array}$ & $\begin{array}{l}\text { Employer and } \\
\text { worker exper- } \\
\text { ience of RTW in } \\
\text { small business } \\
\text { settings }\end{array}$ \\
\hline $\begin{array}{l}6 \text { Friesen et } \\
\text { al, } 2001 \\
(25)\end{array}$ & $\begin{array}{l}\text { Mani- } \\
\text { toba, Ca- } \\
\text { nada }\end{array}$ & $\begin{array}{l}\text { Semi-structured inter- } \\
\text { views and focus groups }\end{array}$ & $\begin{array}{l}11 \text { managers, } 4 \text { union or worker } \\
\text { representatives, } 11 \text { occupational } \\
\text { health professionals, } 12 \text { workers, } \\
\text { plus } 16 \text { others including regula- } \\
\text { tory agency, government, } \\
\text { workers groups, compensation } \\
\text { board, occupational therapists }\end{array}$ & $\begin{array}{l}\text { Recruited on basis of their } \\
\text { experience, knowledge or } \\
\text { importance in work injury } \\
\text { field and RTW process in } \\
\text { the workplace }\end{array}$ & High & $\begin{array}{l}\text { Stakeholder } \\
\text { perspectives on } \\
\text { RTW issues }\end{array}$ \\
\hline $\begin{array}{l}7 \text { Habeck et } \\
\text { al, } 1998 \\
(35)\end{array}$ & $\begin{array}{l}\text { Michigan, } \\
\text { United } \\
\text { States }\end{array}$ & $\begin{array}{l}\text { Part of a larger quantitative } \\
\text { study on workplace poli- } \\
\text { cies, practices, and work } \\
\text { disability; interviews with } \\
\text { employers and document } \\
\text { review; some site tours }\end{array}$ & $\begin{array}{l}32 \text { site visits, each involving } \\
1-4 \text { people }\end{array}$ & $\begin{array}{l}\text { Companies chosen randomly } \\
\text { from systematic sample of } \\
\text { high- and low-performance } \\
\text { companies (based on lost } \\
\text { workdays) in } 6 \text { industry and } \\
3 \text { size categories, recruited } \\
\text { by letters to companies chosen }\end{array}$ & Medium & $\begin{array}{l}\text { Implementation } \\
\text { of RTW policies } \\
\text { and practices }\end{array}$ \\
\hline $\begin{array}{l}8 \text { Innes \& } \\
2002(34) \\
\text { Straker, }\end{array}$ & Australia & $\begin{array}{l}\text { Semi-structured interviews } \\
\text { and one focus group }\end{array}$ & $\begin{array}{l}26 \text { providers of work-related } \\
\text { therapists, } 8 \text { physiotherapists) } \\
\text { assessments ( } 18 \text { occupational }\end{array}$ & $\begin{array}{l}\text { Recruited through personal } \\
\text { groups, at a national conference } \\
\text { contacts, professional interest } \\
\text { and by snowball sample }\end{array}$ & High & $\begin{array}{l}\text { Therapists' be- } \\
\text { liefs about work- } \\
\text { place-based } \\
\text { assessments }\end{array}$ \\
\hline $\begin{array}{l}9 \text { Kenny, } \\
1995 \text { (29) }\end{array}$ & $\begin{array}{l}\text { New } \\
\text { South } \\
\text { Wales, } \\
\text { Australia }\end{array}$ & $\begin{array}{l}\text { Structured interviews with } \\
\text { injured workers, involving } \\
\text { open-ended questions; } \\
\text { mix of qualitative and } \\
\text { guantitative methods }\end{array}$ & $\begin{array}{l}12 \text { injured workers ( } 8 \text { women, } \\
4 \text { men, age } 24-61 \text { years) off } \\
\text { work for more than } 26 \text { weeks }\end{array}$ & $\begin{array}{l}\text { Referred by representative of } \\
\text { the Labour Council of New } \\
\text { South Wales, who was involved } \\
\text { in injured workers advocacy }\end{array}$ & Medium & $\begin{array}{l}\text { Experiences of } \\
\text { long-term injured } \\
\text { workers }\end{array}$ \\
\hline $\begin{array}{l}10 \text { Larsson \& } \\
\text { Gard, } 2003 \\
\text { (28) }\end{array}$ & $\begin{array}{l}\text { Northern } \\
\text { Sweden }\end{array}$ & Interviews with employers & $\begin{array}{l}10 \text { managers in organizations of } \\
\text { different rural areas, differed in } \\
\text { age, experience with rehabilita- } \\
\text { tion planning, size of company }\end{array}$ & $\begin{array}{l}\text { Recruited employers who had } \\
\text { sent workers with musculo- } \\
\text { skeletal problems to a 3-week } \\
\text { vocational rehabilitation } \\
\text { program }\end{array}$ & Medium & $\begin{array}{l}\text { Employers' } \\
\text { experiences with } \\
\text { work rehabilita- } \\
\text { tion planning } \\
\text { process }\end{array}$ \\
\hline $\begin{array}{l}11 \text { Nordqvist } \\
\text { et al, } 2003 \\
\text { (33) }\end{array}$ & $\begin{array}{l}\text { Southern } \\
\text { Sweden }\end{array}$ & $\begin{array}{l}\text { Part of larger cohort study } \\
\text { of injured workers off work } \\
\text { for at least } 28 \text { days; five } \\
\text { focus groups with workers }\end{array}$ & $\begin{array}{l}18 \text { workers ( } 13 \text { women, } 5 \text { men) } \\
\text { with previous low-back injuries }\end{array}$ & $\begin{array}{l}\text { Participants chosen from res- } \\
\text { pondents to a } 1996 \text { question- } \\
\text { naire, recruited by letter }\end{array}$ & Medium & $\begin{array}{l}\text { Laypersons' } \\
\text { views of } \\
\text { employer RTW } \\
\text { role }\end{array}$ \\
\hline $\begin{array}{l}12 \text { Roberts- } \\
\text { Yates, } \\
2003 \text { (32) }\end{array}$ & $\begin{array}{l}\text { South } \\
\text { Australia }\end{array}$ & $\begin{array}{l}\text { Interviews with injured } \\
\text { workers }\end{array}$ & $\begin{array}{l}85 \text { injured workers ( } 37 \text { women, } \\
48 \text { men, age } 25-65 \text { ) from wide } \\
\text { variety of jobs, different RTW } \\
\text { experiences }\end{array}$ & $\begin{array}{l}\text { Workers referred from a net- } \\
\text { work of employers, advocacy } \\
\text { groups, treating medical practi- } \\
\text { tioners and other contacts }\end{array}$ & Medium & $\begin{array}{l}\text { Experiences of } \\
\text { workers with } \\
\text { complex claims }\end{array}$ \\
\hline $\begin{array}{l}13 \text { Shaw et al, } \\
2003(23)\end{array}$ & $\begin{array}{l}\text { North- } \\
\text { eastern } \\
\text { United } \\
\text { States }\end{array}$ & $\begin{array}{l}\text { Semi-structured interviews } \\
\text { with workers }\end{array}$ & $\begin{array}{l}30 \text { nonsupervisory employees } \\
\text { (11 women, } 19 \text { men, job tenure } \\
4 \text { months }-19 \text { years) from four } \\
\text { companies in high physical work } \\
\text { demand or injury rate industries }\end{array}$ & $\begin{array}{l}\text { Participants selected by corpo- } \\
\text { rate health \& safety managers, } \\
\text { companies recruited via busi- } \\
\text { ness and research ties with } \\
\text { funder }\end{array}$ & High & $\begin{array}{l}\text { Role of super- } \\
\text { visors to prevent } \\
\text { workplace } \\
\text { disability }\end{array}$ \\
\hline
\end{tabular}

health care systems that hinder workers' ability to negotiate a complex path to return to work. For instance, in various Canadian jurisdictions, the system is set up in a way that workers are expected to be self-reliant, to assert their legal rights, and to balance the demands of the workplace, insurers and health professionals during 


\section{The steps taken in completing our Systematic Review}

\section{Step 1: Develop Focus: Workplace- Based Return-to-work}

\section{Step 2: Conduct Literature Search (Qualitative and Quantitative):}

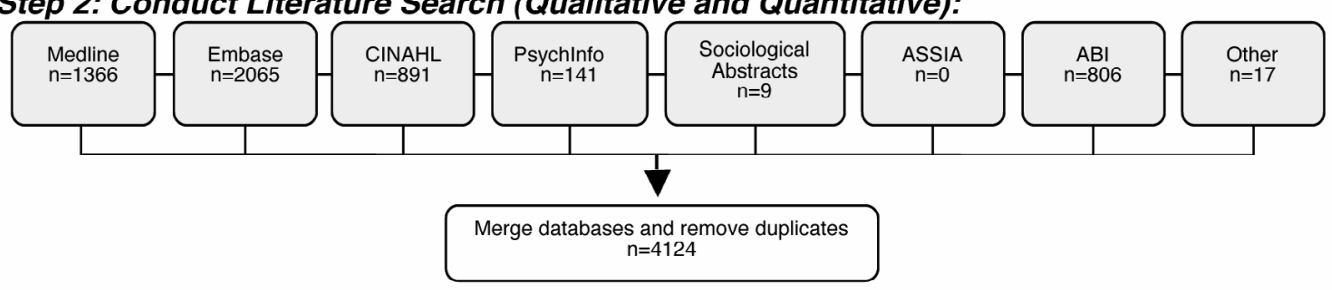

Step 3: Identify Relevant Qualitative Studies:

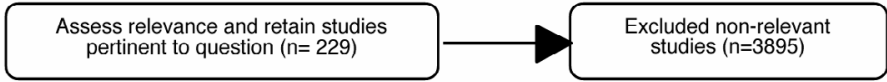

Step 4: Assess the Quality of Relevant Qualitative Studies:

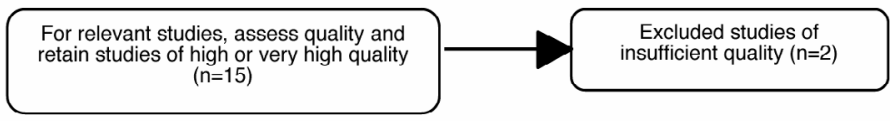

Step 5: Conduct Evidence Synthesis and Generate Report:

Using relevant studies of sufficient quality, develop summary tables and complete evidence synthesis $(n=13)$

Figure 1. Flow chart of studies in the literature review.

the process of recovery and return to work $(25,26)$. However, injured workers are reported as feeling vulnerable and less than self-reliant- they are unsure about process, procedures, and entitlements, and they may lack guidance or support from their workplace $(25,26,30$, 32 ). Workers often do not understand the rules about workers' compensation or the language used by providers. This lack of knowledge of process and procedures can set the stage for problematic rehabilitation, misunderstandings between workers and their workplace, and poor strategizing with respect to health care and return to work (29-31).

Studies have pointed out that, even when injured workers are advised about processes and procedures, the system requirements can be difficult to meet. For instance, injured workers can have a difficult time documenting events for the compensation board while also trying to get on with their physical rehabilitation, disrupted personal lives, and worktasks and relations (27). Workers also have problems cooperating with returnto-work mandates because this "cooperation" is a negotiated process with no clear guidance on exactly how and when to fulfill this duty (26).

Contact with worker between injury and return to work. Early contact with injured workers is a part of many return-to-work programs, and several studies characterized this contact as a time when future cooperation, flexibility, and credibility are at stake. A friendly social phone call from a workplace can be a motivator for workers considering return to work; this kind of contact reminds them that they have not been forgotten (33). Two studies reported return-to-work processes that worked well when employers initiated the rehabilitation process right after injury and did not wait for an insurer, health professional, or worker to make arrangements $(25,28)$.

Some studies showed that there are occasions when neither the worker nor their employer are in the right mind set to be in contact immediately following an injury. Early contact was unhelpful when the worker, for example, had performance problems or had pre-injury problems with workplace relations (31). Early contact can also be problematic when the worker senses that the employer is not forthcoming about support and reintegration or is unhelpful about worker rights and entitlements (29). Because early contact is often a required part of the return-to-work process, it can be perceived by both workers and employers as an unwelcome obligation rather than as care-oriented (26).

Employer contact with physicians. The studies reviewed found that employers experienced difficulties coordinating with physicians when they attempted to set up physically appropriate return-to-work arrangements for injured workers. Several studies describe employers having difficulty with physicians who are hard to contact and who do not promote or assist with early return to work for workers (31). Recommended practices of returning to work prior to complete resolution of an 
injury are not always supported by treating physicians, and some arrive at diagnoses that involve prolonged treatments and absence from work (27). Physician contact and the timing of return to work is problematic for employers when they need additional physician input about a worker's ability in relation to particular worktasks before they can design an appropriate modified job for an injured worker. Workplace visits that could allow for a full understanding of an injured worker's return-to-work needs are outside the range of normal physician activity, and physicians lack employers' financial motivation to promote early return to work (25). This disconnect between employers and physicians can lead to difficulties for workplace parties as they attempt to comply with early return-to-work requirements $(26,29)$.

When employers do not coordinate closely with treating physicians, they can be drawn inappropriately into workers' treatment issues. One study showed that employers who have difficulty contacting physicians or who feel that physicians delay worker return to work can end up taking on the role of mediating and coordinating medical aspects of the return-to-work process (26). In many jurisdictions, confidentiality rules allow employers to know only the functional abilities of an injured worker, but, with early return requirements, employers can be drawn into taking an interest in workers' medical progress. In this context, particularly in smaller firms, employers learn details of treatment and make personal judgments about workers' abilities and recovery pace. This situation draws employers inappropriately into practical decisions about workers' injuries and recovery.

One study of workplace assessments of disability management conducted by therapists found that these workplace evaluations can be sensitive to organizational and industrial relations issues such as restructuring, changes in staff numbers, and the sociocultural environment. Therapist visits can offer a view of the worker situation, which includes relevant aspects of the job and work environment (34). This synthesis suggests that intermediary health care professionals may be in a key position to bridge return-to-work planning gaps between employers, busy physicians, and injured workers.

Modified work-social, physical and financial aspects. Once early contact requirements have been fulfilled and workers have been assessed for functional ability, employers begin to consider appropriate modified work for injured workers. The studies reviewed refer to social, physical, and financial components of modified work that need to be considered in order to achieve adequate modified work conditions. Workable modified work arrangements were described as flexible, tailored to the worker's particular needs $(30,35)$, and having production value (24).
Social aspects of modified work included relationships between injured workers and their co-workers and social dislocation. Co-workers may resent the injured worker if they have to take over some of his or her workload or if the injured worker gets an "easier" job-especially when this job has been co-opted from another worker (28). They may also feel that the presence of an injured worker has an adverse effect on the group's production statistics and production-related bonus opportunities. Co-workers may be suspicious about the extent and duration of an injured worker's injury (32) and unwilling to assist an injured worker with tasks (31). Difficult relations between an injured worker and his or her co-workers may be compounded because injured workers can have difficulty telling colleagues about their restrictions and asking for help and because they may alienate co-workers when their functional restrictions lead them to refuse another worker's request for assistance $(27,32)$. One study suggested that re-injury is influenced by these aspects of co-worker relations during periods of modified work (33).

Social dislocation can arise during modified work if the worker is placed temporarily in a new work area and must adjust to a new set of relationships, routines, and sometimes new behavioral requirements (26). For instance, a male truck driver may be given "light" work in a female-dominated office, where he feels socially and physically ill at ease. Such social aspects of modified work may have a strong impact on the success or failure of an arrangement, as modified work that is socially awkward can be resisted by the worker $(28,31$, 32).

A second component of the modified work referred to in the studies reviewed is the physical arrangement of work. One study noted that when modified work is planned, the selection of tasks is usually left to the supervisor and is rarely based on ergonomic considerations (31). This situation can be a problem because, if work is not tailored to a worker's particular needs, it may predispose the worker to re-injury (30). If the job modification requires them to take over some of the injured worker's duties, the physical arrangement of modified work may also increase co-worker workload and risk of injury (28).

A third component of modified work is financial. It includes employer costs associated with keeping a job open, modifying tasks, and paying workers' compensation premium surcharges. Employers may be reluctant to incur the costs of changed procedures and individual worker accommodation (28). Where employers find that the provision of appropriate modified work is difficult or expensive, workers may be given meaningless work so that employers can keep workers "at work" and therefore avoid workers' compensation premium surcharges $(24,26,27)$. 
Role of unions in return to work. Union organizations and union members in some workplaces support return to work and promote the practice of modified work, especially when the union is a full partner in the development and implementation of the return-to-work program (27). However, the studies reviewed identified ways that union support for return to work can be side-tracked by practical workplace considerations. Return-to-work legislation can set unions at odds with return-to-work plans because the requirement to provide alternative or modified work can conflict with seniority clauses in collective agreements. In addition, jurisdictional issues with multiple unions within a workplace can hinder cooperation with respect to temporary reassignments for modified work $(24,27)$. Unions can also be reluctant to facilitate modified work arrangements if they support the right of workers to stay off work while they cannot do their job and if they (similar to some physicians as noted above) have not fully accepted the principle of "early" return to work before full recovery (31). Union support for return to work may be tempered by sensitivities to production statistics as an important priority of management, views of return to work as a cost-saving mechanism, and worker's obligations to return to modified work without voluntary consent (24).

Role of supervisors in the day-to-day social relations of return to work. Several studies pointed to supervisors as important to the success of return to work because of their daily proximity to the worker. The role of the supervisor is not usually to make major workplace changes that may alter the physical or organizational environment, but within an organization's existing conditions supervisors are uniquely situated to manage the day-today social relations and physical conditions in the work environment. The supervisor role in physical aspects of work accommodation involves the implementation and regular monitoring of a safe and appropriate modified work environment for the injured worker. They are in a position to monitor modified work and to ensure that it is meaningful to the injured worker (23). Because production needs can change and workers can be reluctant to complain about breaches of physical restrictions, supervisors who are on location can consider appropriate concurrent changes to modify work (29). Therefore, supervisors are an important source of certainty that restrictions are upheld $(27,29)$. They can also monitor worker job practices and habits. For example, one study described how workers returned from off-site rehabilitation and reverted to unsafe work techniques (28). Therefore, supervisors engaged in return-to-work processes may be well situated to ensure the proper adjustment of workers to their previous job.

The supervisor can also be a well-placed advocate who can lend legitimacy to a worker's condition and restrictions, validate the injury, and smooth difficult workplace relations (as described earlier) between the injured worker and his or her co-workers $(23,27,29$, $33)$. One study suggested that even when the workplace has an on-site nurse who is managing a return-to-work program, the supervisor should still be closely involved because he or she is present every day, has the closest contact with worker, and is aware of social dynamics that may help or hinder the return-to-work process (23).

This synthesis found that supervisors can play an important intermediary role in physical and social aspects of work accommodation. However, in order to enable and encourage supervisors to manage social and physical aspects of return to work, workplaces may need to remove disincentives for the supervisor to engage with the process. Several studies mentioned obstacles to the supervisor's role in return to work. They may lack skills for managing complex psychosocial workplace dynamics. They may also lack training about ergonomic principles and how to keep work within the injured worker's restrictions (31). There can be a lack of managerial consensus about return-to-work processes (24), and the return-to-work role may be an unwanted burden, especially when conflicting priorities orient the supervisor to see return to work as an obstacle to production (24, 31 ). In addition, supervisors may not have enough time to manage nonproduction needs such as the extra social and physical needs of return to work (33).

Return to work and organizational environments. This review identified two aspects of organizational environments that can affect return to work, economic context and internal dynamics. The economic context of the work organization can affect internal practices related to return to work, as growing companies will acquire personnel and expertise and will have greater flexibility to arrange modified positions. However, if an organization is downsizing, reduced jobs for everyone means that organizations will have difficulty finding modified work for injured workers $(24,25)$. With financial constraints, there may be increased emphasis on the management of claims, with health aspects of return to work outweighed by financial concerns (27).

Even when an organization is in good fiscal condition, workplace parties may not always accept the return-to-work mandate. At least, in the short term, return to work can be expensive, with increased personnel effort and time (27). In some cases, this situation may override the financial incentives of workers' compensation premiums to initiate return to work. Distractions and disincentives to return to work can multiply when organizations do not explicitly endorse the return-towork process and, thereby, give it credibility among managers, union leaders, and supervisors $(25,27)$. In addition, managerial consensus about how to achieve 
return to work in the organization is needed, together with methods for tracking and disseminating information about workplace injury $(33,35)$.

\section{Discussion}

An analysis of the eight key concepts yields three main findings from this synthesis of qualitative literature on workplace-based return to work. The first finding relates to the scope and complexity of workplace-based returnto-work processes. We found that return to work involves more players and dimensions than were identified in any one study. Our findings about the role of workers, co-workers, employers, health professionals, unions, organizational environments, and the workers' compensation and health care systems as they interact with each other to support or undermine the possibility of appropriate modified or return-to-work conditions provide a comprehensive and detailed picture of return to work that extends beyond the current literature. Return to work therefore extends well beyond local concerns about managing injured worker physical function to broader complexities related to work organization and the beliefs and roles of a myriad of players. Successful outcomes will require active planning and sensitivity to the complexity of the process.

Our second synthesis finding relates to the role of goodwill and trust as overarching conditions that are central to return-to-work arrangements. While the term "goodwill" was not directly mentioned in any of the studies reviewed, almost all of the studies reviewed pointed implicitly to this intangible, but influential aspect of social environments. In this synthesis, "goodwill and trust" was a key concept and also a cross-cutting theme. For instance, other key concepts that focused on the role of early contact, unions, supervisors, and modified work conditions each pointed to the potential for conflict and the importance of considerate understanding of mutual needs. Our finding of the relevance of goodwill highlights the need for creativity and good teamwork in return to work. Because every workplace is different, employers and other players must be motivated and also aware of opportunities for viable modified work (28).

Our third synthesis result builds on the two findings already presented. Our findings about the scope and complexity of the return-to-work process and the importance of social conditions of goodwill and trust provide insight into particular social and communication barriers and needs in the return-to-work process. Because of the differing players in the return-to-work process, there is a built-in challenge for communication and coordination, and so we found that intermediary players have the potential to play a key role in facilitating the return-to-work process. More specifically, we identified two key intermediary players, rehabilitation or occupational health care providers and workplace supervisors. Because employers experience difficulty coordinating details of return-to-work arrangements with busy or disinterested physicians, a rehabilitation or occupational health care provider can play an important role in the facilitation and moderation of return-to-work communication. This intermediary health care professional can visit the workplace, gain a close understanding of the needs of the injured worker, and liaise between the physician and the employer. Workplace supervisors can also play an important intermediary role in return to work by sustaining positive day-to-day social relations between the injured worker and his or her co-workers and by maintaining the accommodation of the physical environment amidst changing production conditions. In addition, supervisors provide a regular link between the worker and upper management.

In summary, we have described how concepts in the papers reviewed lead to eight key concepts that are relevant to the return-to-work process. An analysis of the key concepts resulted in three overall synthesis conclusions about the complexity of the process, overarching social conditions related to goodwill and trust, and the relevance of two key intermediary players in the returnto-work process.

\section{Meta-ethnographic synthesis process}

Britten et al (21) noted that meta-ethnographic syntheses cannot be reduced to a set of mechanistic tasks but that a synthesis will generally consist of series of steps, or building blocks, geared to the derivation of interpretations relevant to the synthesis question or topic. In our systematic review, our research questions about dimensions, processes, and practices in return to work guided our inquiry of the papers reviewed. We found that the compilation of findings in key concepts provided a broad and detailed picture of the return-to-work process. The key concepts then provided a platform for analysis leading to conceptual development about the returnto-work process that extends beyond that in any one empirical study. Overall, we were able to gain new explanations not articulated in the literature from the synthesis findings, as well as observations that, in some cases, were peripheral to the authors' original research question, but which were central to our own research question.

We placed our findings in a broad "realist" perspective (13) that takes an explanatory focus and unpacks mechanisms of how complex programs work. Our findings acknowledge meaningful and intentional behavior of actors and also recognize that behavior is limited and shaped by social structure. For instance, we acknowledge 
the potential worker advocacy role for workplace supervisors in return to work, but we also highlight broader conditions of the possibility for supervisor behavior, such as a lack of managerial consensus about return-to-work processes and conflicting priorities that orient the supervisor to see return to work as an unwanted obstacle to their own goals.

\section{Future research}

This review identifies several directions for future research and systematic reviews. Many of the reviewed studies focused on return to work at one point in time. A trajectory approach to both workers and workplaces is required for a better picture of the sustainability of return-to-work initiatives and organizational change during this process. The importance of following workers over time has been highlighted in quantitative research (36); a qualitative study that followed the course of the return-to-work process over an extended period could greatly enhance our understanding of the evolution of the return-to-work process over time. Other research may be directed towards the sustainability of return-to-work interventions from an organizational perspective-how can employers maintain a worker in a modified position over time, especially when there are economic constraints or organizational changes or when the worker requires long-term accommodation due to permanent disability?

The reviewed studies focused on return to work following a physical disability. Future research may also include a focus on the mental health of injured workers-for instance, what is the relationship between depression and unsuccessful return to work? How do return-to-work programs for physically injured workers differ from those of people with other health conditions, including mental health issues? Research may focus on the areas of promise identified in this review, for instance, the role of intermediary health care providers and supervisors, each of which requires identification models for practice.

Finally, future systematic reviews of qualitative studies can further explore the role of theory in synthesis. High-level qualitative studies achieve their ratings of quality precisely because of theoretical frameworks that guide the research question, data gathering process, and analysis. Given this prominent role of theory in qualitative research, future synthesis of qualitative studies can provide theoretical underpinnings of the studies reviewed and also of the final synthesis.

\section{Strengths and limitations}

A strength of this synthesis was that we reviewed available tools for the evaluation of the quality of qualita- tive studies before choosing the tool used in this review (14). The quality assessment tool we used avoids constraints posed by a rigid "checklist" approach to quality; it offers frameworks sensitive to variance among qualitative studies and with sufficient strength for a consistency of judgment and process. An additional strength of this synthesis was that, although the meta-ethnographic approach does not explicitly consider the theoretical dimension of this synthesis, its procedures allow the researcher to consider the original theoretical perspective of the studies and to synthesize findings into a common theoretical perspective.

A limitation of this review was the paucity of highquality qualitative research relevant to the topic of workplace-based return to work. So that a sufficient body of literature would be included in this review, our criteria for quality assessment excluded only 2 of the 15 studies that had been screened for methodological and topical relevance. These final studies included seven which were of "medium" quality and which contained a relatively "thin" picture of return-to-work conditions. Under optimal conditions, we would only have included studies with a stronger level of analysis that included theory and took into consideration complexities of the local and broader environment. However, on the whole, we found that the "medium" level studies made a worthwhile contribution to the process of constant comparison and negative case analysis and to an aggregate picture of the process of return to work after injury.

In summary, this synthesis has brought together research findings from a range of qualitative studies on the theme of workplace-based return to work and has identified key mechanisms of workplace practice, process, and environment that can affect the success of return to work. The strength of this systematic review is that it has shown the contribution that qualitative literature can make to important aspects of process, social relations, and implementation in relation to return to work. In addition, the findings of this synthesis of qualitative literature have identified key elements in return to work that are relevant to practitioners and stakeholders and have pointed to areas of conceptual promise that may direct researchers to further study.

\section{Acknowledgments}

This study was supported by the Workplace Safety \& Insurance Board and the Institute for Work \& Health.

We also acknowledge the Workplace-based Return to Work Literature Review Group for their overall support and their feedback on iterations of these findings, and Lori Chambers for her editorial assistance. We 
thank the anonymous reviewers for their helpful comments on the presentation of the synthesis analysis.

\section{References}

1. Krause N, Dasinger LK, Neuhauser F. Modified work and return to work: a review of the literature. J Occup Rehabil. 1998;8(2):113-39.

2. Saroki FJ, Welch EM. Return to work-proof that it works. On Work Compens. 1997;7(2):9-10.

3. Galvin DE, Schwartz G. Employer-based disability management and rehabilitation initiatives. Washington (DC): D:ATA Institute; 1986.

4. Shrey DE. Disability management in industry: the new paradigm in injured worker rehabilitation. Disabil Rehabil. 1996; 18(8):408-14.

5. Franche R-L, Cullen K, Clarke J, MacEachen E, Frank J, Sinclair S, et al. Workplace-based return-to-work interventions: a systematic review of the quantitative and qualitative literature [report]. Toronto (ON): Institute for Work \& Health; 2004.

6. MacEachen E, Clarke J, Franche R-L, Cullen K, Sinclair S, Frank J, et al. What systematic reviews gain when they include qualitative research: a systematic review of qualitative work on workplace-based return-to-work practices. [Abstract available at http://www.cochrane.org/colloquia/abstracts/ottawa/O-087.htm].

7. Franche R-L, Cullen K, Clarke J, Irvin E, Sinclair S, Frank J, et al. Workplace-based return-to-work interventions: a systematic review of the literature. J Occup Rehabil. 2005; 15(4):607-31.

8. Thomas J, Harden A, Oakley A, Oliver S, Sutcliffe K, Rees R, et al. Integrating qualitative research with trials in systematic reviews. Br Med J. 2004;328:1010-3.

9. Popay J, Roen K. Using evidence from diverse research designs [report]. London: Social Care Institute for Excellence; 2003.

10. Harden A, Garcia J, Oliver S, Rees R, Shepherd J, Brunton G, et al. Applying systematic review methods to studies of people's views: an example from public health research. J Epidemiol Community Health. 2004;58:794-800.

11. Dixon-Woods M, Fitzpatrick R. Qualitative research in systematic reviews. Br Med J. 2001;323:765-6.

12. Hawker S, Payne S, Kerr C, Hardey M, Powell J. Appraising the evidence: reviewing disparate data systematically. Qual Health Res. 2002;12(9):1284-99.

13. Pawson R, Greenhalgh T, Harvey G, Walshe K. Realist review - a new method of systematic review designed for complex policy interventions. J Health Serv Res Policy. 2005;10(3 Suppl 1):21-34.

14. Spencer L, Ritchie J, Lewis J, Dillon L. Quality in qualitative evaluation: a framework for assessing research evidence [occasional paper]. London: Government Chief Social Researcher's Office; 2003. No 2 (i-98).

15. Eakin JE, Mykhalovskiy E. Reframing the evaluation of qualitative health research: reflections on a review of appraisal guidelines in the health sciences. J Eval Clin Pract. 2003;9(2):187-94.

16. Seale C. Quality in qualitative research. In: Lincoln YS, Denzin NK, editors. Turning points in qualitative research: tying knots in a handkerchief. London: AltaMira; 2003. p 169-84.
17. Mays N, Pope C. Qualitative research in health care: assessing quality in qualitative research. Br Med J. 2000;320:50-2.

18. Barbour RS, Barbour M. Evaluating and synthesizing qualitative research: the need to develop a distinctive approach. J Eval Clin Pract. 2003;9(2):179-86.

19. Seale C. The quality of qualitative research. Thousand Oaks (CA): Sage; 1999.

20. Noblit GW, Hare RD. Meta-ethnography: synthesizing qualitative studies. London: Sage; 1988.

21. Britten N, Campbell R, Pope C, Donovan J, Morgan M, Pill R. Using meta ethnography to synthesise qualitative research: a worked example. J Health Serv Res Policy. 2002;7(4):209_ 15.

22. Campbell R, Pound P, Pope C, Britten N, Pill R, Morgan M, et al. Evaluating meta-ethnography: a synthesis of qualitative research on lay experiences of diabetes and diabetes care. Soc Sci Med. 2003;56:671-84.

23. Shaw WS, Robertson MM, Pransky G, McLellan RK. Employee perspectives on the role of supervisors to prevent workplace disability after injuries. J Occup Rehabil. 2003;13(3):129-42.

24. Baril R, Berthelette D. Components and organizational determinants of workplace interventions designed to facilitate early return to work [report]. Montreal (QC): Institut de Recherche Robert-Sauvé en Santé et en Sécurité du Travail (IRSST); 2000. Etudes et recherches, no R-263(i-53).

25. Friesen MN, Yassi A, Cooper J. Return-to-work: the importance of human interactions and organizational structures. Work. 2001;17(1):11-22.

26. Eakin JM, MacEachen E, Clarke J. 'Playing it smart' with return to work: small workplace experience under Ontario's policy of self-reliance and early return. Policy Pract Health Saf. 2004;1(2):19-41.

27. Clarke J, Cole D, Ferrier S. Return to work after a soft tissue injury: a qualitative exploration [working paper]. Toronto (ON): Institute for Work \& Health; 2002. No 127.

28. Larsson A, Gard G. How can the rehabilitation planning process at the workplace be improved? a qualitative study from employers' perspective. J Occup Rehabil. 2003;13(3):16981.

29. Kenny D. Barriers to occupational rehabilitation: an exploratory study of long-term injured workers. J Occup Health Saf Aust N Z. 1995;11(3):249-56.

30. Baril R, Martin J-C, Lapointe C, Massicotte P. Etude exploratoire des processus de reinsertion sociale et professionnelle des travailleurs en readaptation [Exploratory study of the social and professional reintegration process of workers undergoing rehabilitation]. Montreal (QC): Institut de Recherche Robert-Sauvé en Santé et en Sécurité du Travail (IRSST); 1994. No, RR-082. p 1-17.

31. Baril R, Clarke J, Friesen M, Stock S, Cole D, Bombardier C, et al. Management of return-to-work programs for workers with musculoskeletal disorders: a qualitative study in three Canadian provinces. Soc Sci Med. 2003;57(11):2101-14.

32. Roberts-Yates $\mathrm{C}$. The concerns and issues of injured workers in relation to claims/injury management and rehabilitation: the need for new operational frameworks. Disabil Rehabil. 2003;25(16):898-907.

33. Nordqvist C, Holmqvist C, Alexanderson K. Views of laypersons on the role employers play in return to work when sicklisted. J Occup Rehabil. 2003;13(1):11-20.

34. Innes E, Straker L. Workplace assessments and functional capacity evaluations: current practices of therapists in Australia. Work. 2002;18(1):51-66. 
35. Habeck RV, Scully SM, VanTol B, Hunt HA. Successful employer strategies for preventing and managing disability. Rehabil Couns Bull. 1998;42(2):144-61.

36. Krause N, Frank JW, Dasinger LK, Sullivan TJ, Sinclair SJ. Determinants of duration of disability and return-to-work af- ter work-related injury and illness: challenges for future research. Am J Ind Med. 2001;40:464-84.

Received for publication: 12 December 2005

\section{Appendix}

\section{Questions used in the quality assessment}

1. How credible are the findings?

2. How has knowledge/understanding been extended by the research?/

3. How well does the study address the original aims and purpose?

4. Scope for drawing wider inference-how well is this explained?

5. How defensible is the research design?

6. How well defended is the sample design/target selection of cases?

7. Sample composition/case inclusion-how well is coverage described?

8. How well was the data collection carried out?

9. How well was the approach to/formulation of the analysis conveyed?

10. Contexts of data sources-how well are they retained/portrayed?

11. How well has diversity of perspective and content been explored?

12. How well has detail, depth and richness of data been conveyed?

13. How clear are the links between data, interpretation and conclusions?

14. How clear and coherent is the reporting?

15. How clear are the assumptions/theoretical perspectives/values that shaped form and output of the study?

16. What evidence is there of attention to ethical issues?

17. How adequately has the research process been documented? 